\title{
POLLEN MORPHOLOGY OF THE GENUS PHYLLANTHUS (EUPHORBIACEAE)
}

W. PUNT

Botanical Museum and Herbarium, State University, Utrecht (The Netherlands)

(Received September 3, 1966)

(Revised November 24, 1966)

\section{SUMMARY}

Some pollen types occurring in the genus Phyllanthus are arranged into two morphological series. These series are based on seven "evolutionary trends".

\section{INTRODUCTION}

Phyllanthus is the largest and most diversified genus among the genera in the subfamily Phyllanthoideae of the Euphorbiaceae. WEBSTER (1956-1958), at present undertaking a revision of Phyllanthus, estimates the total number of species at 650 and LÉANDRI (1958), in Paris, suggested a probable total of 1,700 species.

The genus includes a great many types of growth from such as trees, shrubs, annuals and perennial herbs. The distribution of the genus is circumtropical and well represented on all continents and particularly on the off-shore island groups such as Cuba, Madagascar and New Caledonia. The present classification of Phyllanthus very inadequately reflects the true relationships between the subgeneric taxa (WEBSTER, 1956).

Phyllanthus in its current circumscription is not entirely a natural genus. There are profound differences in the vegetative structure, flowers and fruits. It is not surprising that the pollen grains in this genus also show an extraordinary diversity of pollen types. In this short report the author will try to give a brief outline of some pollen types and their mutual relationships. The diversity, however, is so large, that such an outline can only be considered incomplete.

METHODS AND TERMINOLOGY

The pollen grains studied were treated according to the acetolysis method described by ERDTMAN in 1943 and revised by him in 1960. The grains have been 
embedded in glycerine-jelly. The microphotographs were taken with a Leity Ortholux microscope, combined with a Leitz Orthomat camera.

The terminology used in this paper is partly after ERDTMAN (1952) and partly after Punt (1962).

\section{TAXONOMICAL AND PHYLOGENETICAL RELATIONSHIPS}

If it is accepted that evolution actually took place, this evolution must be supported by as much data as possible, e.g., palaeobotanical, phytogeographical, cytotaxonomical and other taxonomical data. It is a pity that so little palaeobotanical information is known from Euphorbiaceae-Phyllanthoideae and this is one more reason for accumulating as much recent data as possible before discussing the probable phylogenetical relationships. WEBSTER (1956-1958) has already accumulated much phytomorphological, cytotaxonomical (WEBSTER and ELLIS, 1962) and other taxonomical data. According to these data some species were considered primitive and others appeared to be advanced.

The author felt that pollen morphology might give additional support for the position of Websters primitive and advanced taxa. If, moreover, pollen morphology and taxonomy would arrive at the same conclusion, this would mean a real advance in the subdivision of the genus.

One of the suggestions which Webster made is that there is a relationship between Phyllanthus and the presumably primitive genera Securinega, Andrachne and Savia of the same family (WEBSTER, 1956). If we assume, that some species of Phyllanthus which show relationships with the genera Securinega, Andrachne and Savia are the most primitive ones in this genus, than it seems logical to accept, that the characteristics which the pollen grains of these taxa exhibit are also primitive. Pollen grains of several species of Phyllanthus ( $P$. hamiltonianus, $P$. kirkianus, $P$. maderaspatensis and $P$. profusus) indeed resemble those of Securinega, Andrachne and Savia (Webster, 1956; PUnT, 1962; KöHLER, 1965). These species are tricolporate, distinctly prolate, reticulate and have an elongated endoaperture (Plate IA-D). One thing should be kept in mind, viz. that so-called "primitive" pollen grains of the genus Phyllanthus are already "advanced" in comparison to the other pollen types in the Plant Kingdom, e.g., monoaperturate and 3-colpate grains in Magnoliaceae and Ranunculaceae (ERDTMAN, 1952).

If we accept pollen grains of $P$. maderaspatensis and its allies as being the most primitive in the genus Phyllanthus, then the pollen-morphological characters in other pollen grains are advanced. The evolution of the pollen characters is demonstrated by means of successions which the author calls "evolutionary trends" (Fig.1). In studying the pollen grains of Phyllanthus several of these trends could be distinguished and the most important ones are shown in Table I. There is not a special sequence in which the evolutionary trends occur. All trends may occur at any point in any series of pollen types. 


\section{PLATE I (p.144)}
All magnifications are $\times \mathbf{2 , 0 0 0}$.
A. Andrachne phyllanthoides.
B. Securinega peltandra.
C. Securinega microcarpa; reticulum.
D. Phyllanthus maderaspatensis.
E1. P. acidus; endoporus.
E2. $P$. acidus; colpi anastomosing at the pole.
F1. P. pynaertii; colpi not anastomosing at the pole.
F2. $P$. pynaertii; polar view.
G. P. glaucus; polar view, anastomosing colpi.

\section{PLATE II (p.145)}
All magnifications are $\times 2,000$.
A1. P. casticum; polar view, colpi anastomosing.
A2. P. casticum; equatorial view, endoporus.
B1. P. cryptophilus; reticulum at high focus.
B2. P. cryptophilus; reticulum at low focus, colpus borders at high focus.
B3. P. cryptophilus; double endoporus.
B4. $P$. cryptophilus; single porus in focus, double porus faintly visible in right-hand colpus.
C1. $P$. warburgii; equatorial view; endoporus.
C2. $P$. warburgii; polar view, colpi at high focus.
C3. P. warburgii; colpi at low focus.
D1. P. miquelianus; colpi and endopori in focus.
D2. P. miquelianus; same grain in optical section.
E. P. welwitschianus; endopori.

\section{PLATE III (p.146)}

All magnifications are $\times 2,000$.

A1. $P$. welwitschianus; reticulum and one porus.

A2. $P$. welwitschianus; five colpi.

B1. $P$. websterianus; reticulum.

B2. $P$. websterianus; double porus.

C1. P. fasciculatus; optical section.

C2. P. fasciculatus; reticulum.

\section{PLATE IV (p.147)}

A1. P. emblica; polar view, optical section; magnification $\times 2,000$.

A2. P. emblica; equatorial view, optical section; magnification $\times 2,000$.

A3. P. emblica; colpus and endoporus; magnification $\times 2,000$.

A4. P. emblica; reticulum; magnification $\times 2,000$.

B1. P. ruscifolius; equatorial view, optical section; magnification $\times 1,300$.

B2. $P$. ruscifolius; equatorial view, optical section; magnification $\times 2,000$.

B3. P. ruscifolius; colpus and endoporus; magnification $\times 2,000$. 
PLATE I
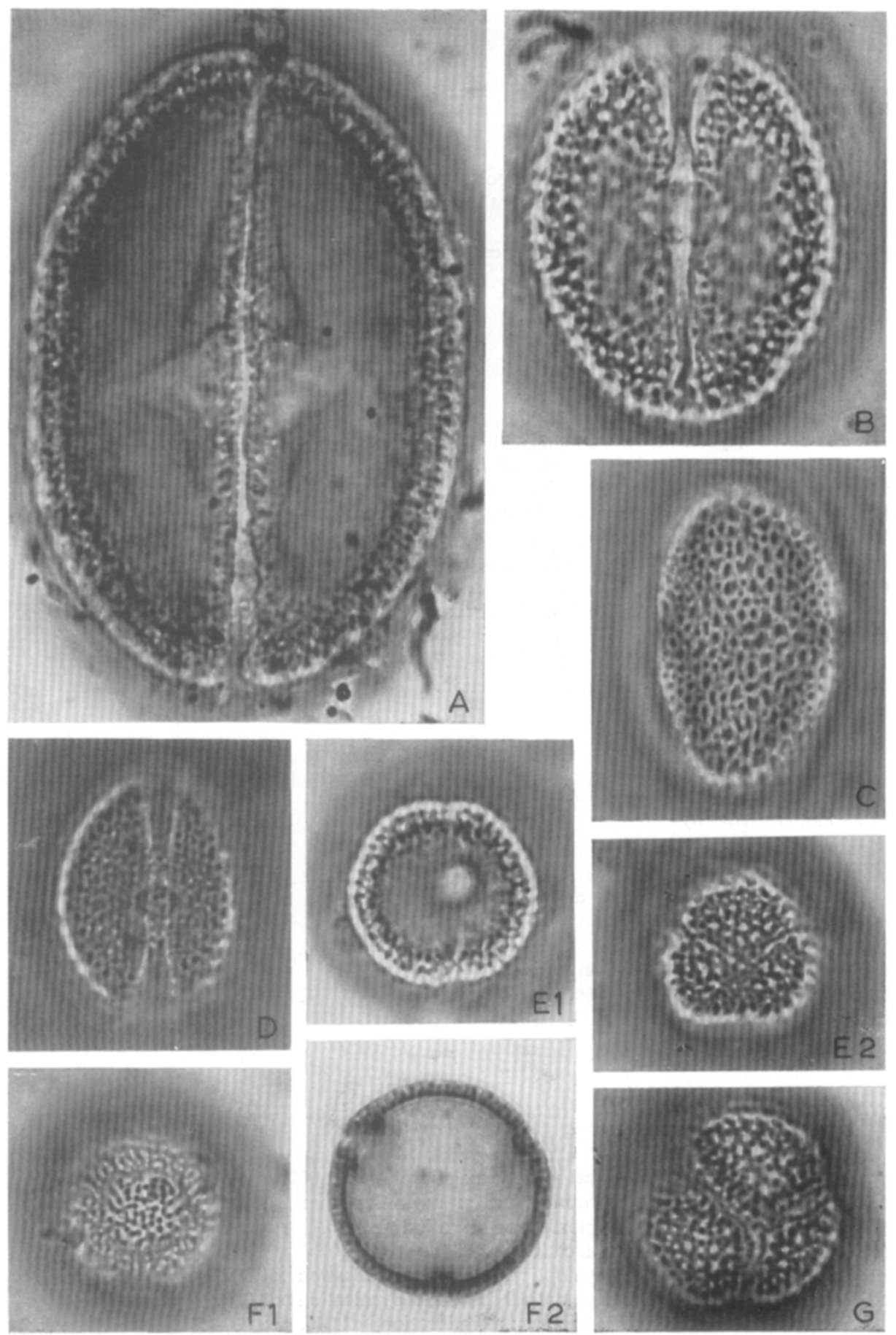


\section{PLATE II}
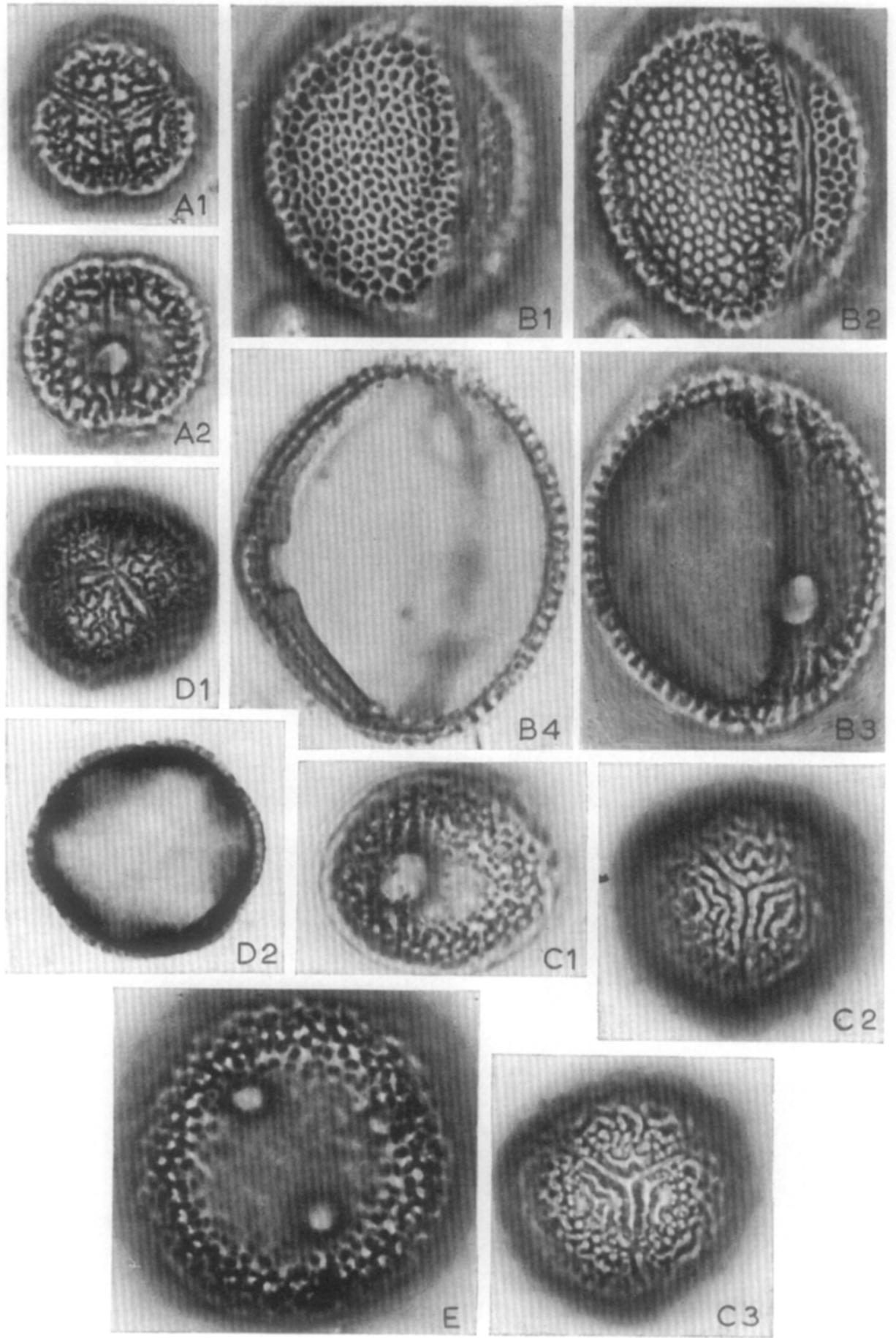
PLATE III
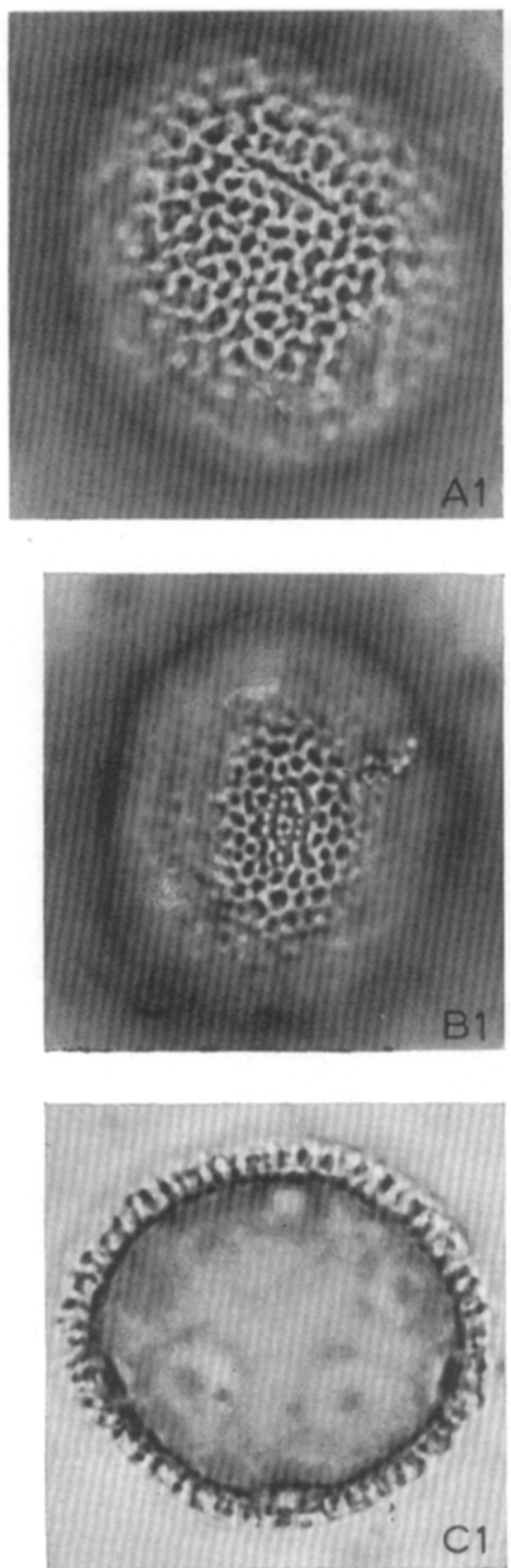
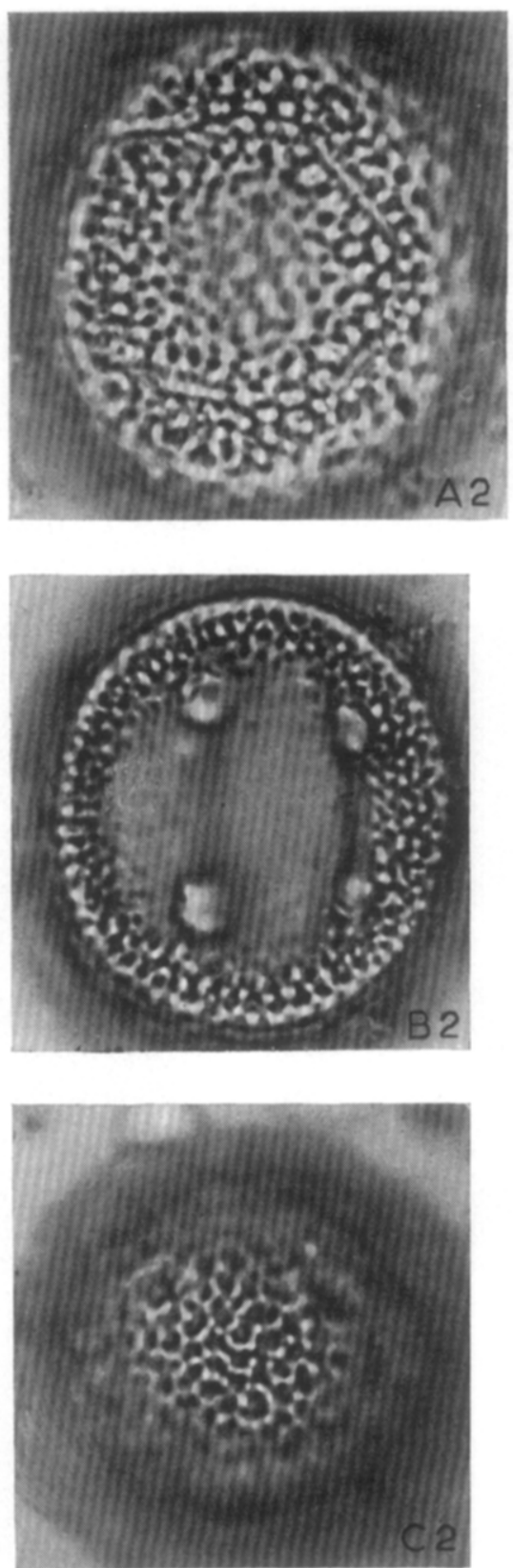
PLATE IV
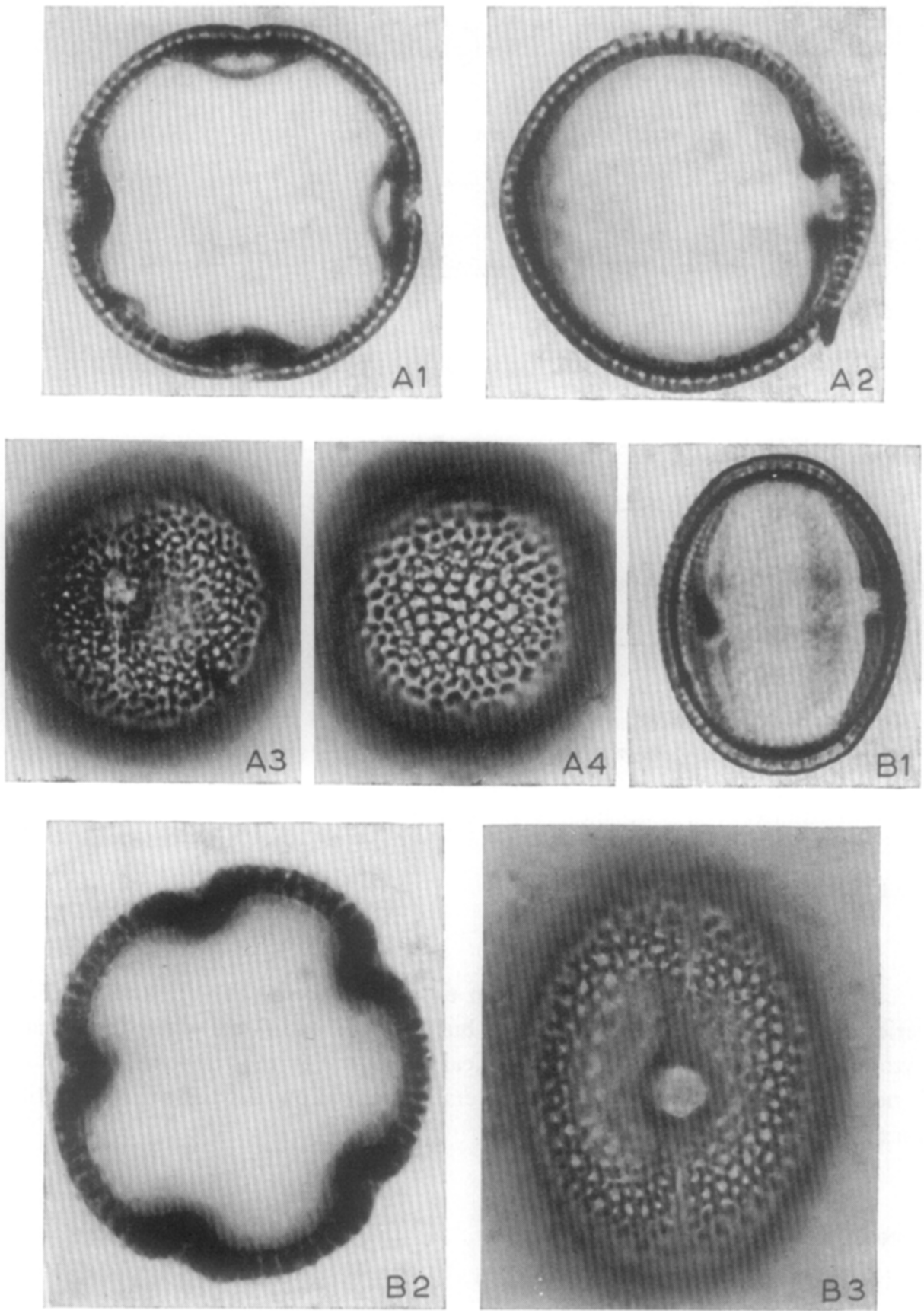

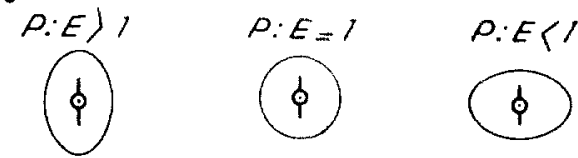

2. Colpe length

colponate syncolponate

A<smiles>CCCCC1CCCC2CCCCC12</smiles>

colponate porate

3. Number of colpes (pores)

$$
\text { 3-colporate - 4-, 5-,6-. plunicolponate }
$$

4 Colpe mangin

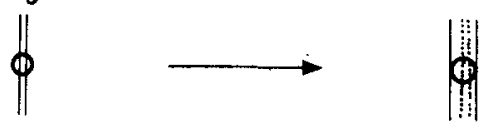

5. Shape of the endoaperture

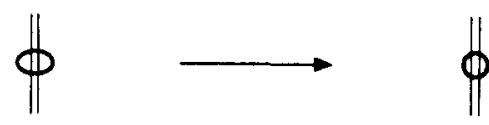

6. Doubling of the endodperture

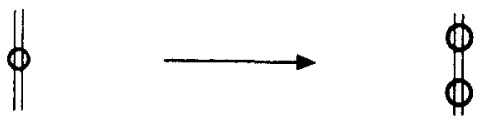

7. (Structure) Ornamentation

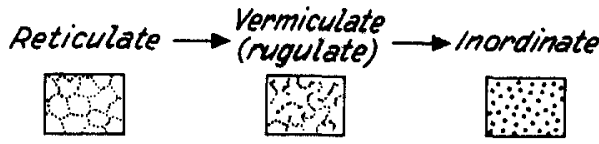

Fig.1. Evolutionary trends.

In this paper two series of pollen types are shown (Table I and II). The series may be of evolutionary value, but because additional palaeobotanical, cytotaxonomical and other morphological evidence for the supposed evolution is not yet available at this moment, it seems better to consider these series for the time being as morphological series only.

\section{CONCLUDING REMARKS}

In addition to the two series shown in Table I and II, it is possible to arrange some more series, taking the $P$. maderaspatensis type as starting point. Space is too limited, however, to show all morphological series. Moreover, it was impossible to 


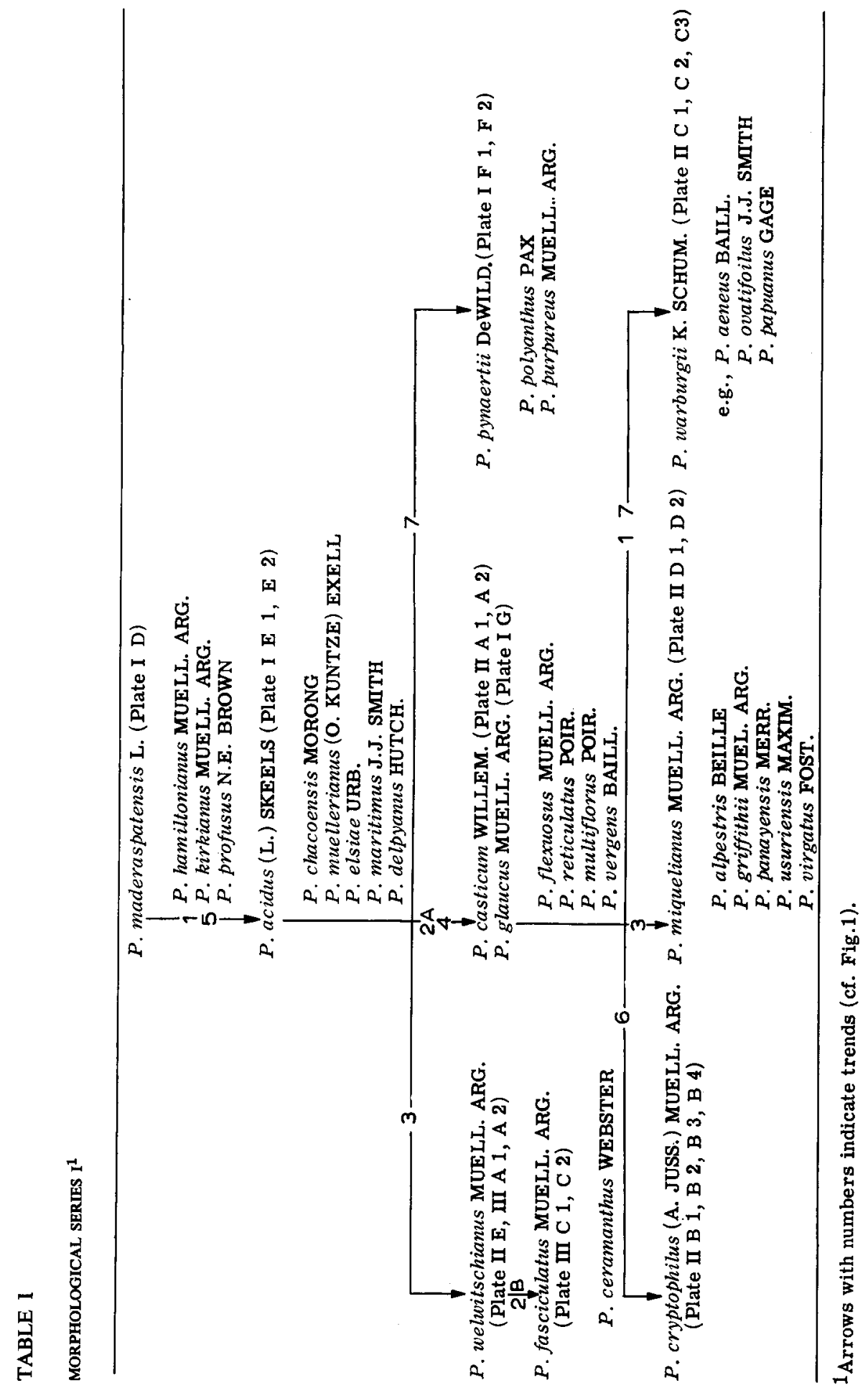

Rev. Palaeobotan. Palynol., 3 (1967) 141-150 
TABLE II

MORPHOLOGICAL SERIES II ${ }^{1}$

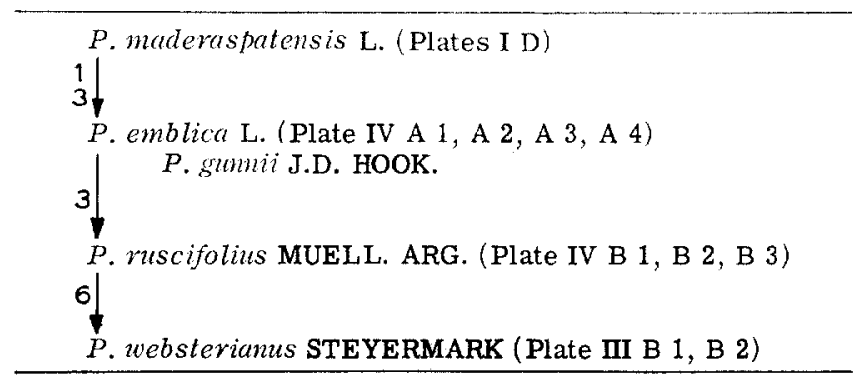

1Arrows with numbers indicate trends (cf. Fig.1).

give any additional information on the taxonomical results in this subject. In collaboration with Professor G. L. Webster, the author is preparing a more detailed classification of the genus Phyllanthus based on both pollen morphology and taxonomy.

\section{ACKNOWLEDGEMENTS}

The present study was done in close cooperation with Professor G. L. Webster, Davis, Calif., U.S.A. Without his kind help, ample advise and critical comment it would have been impossible for the author to communicate the present data.

\section{REFERENCES}

Erdtman, G., 1943. An Introduction to Pollen Analysis. Chronica Botanica Co., Waltham, Mass., $239 \mathrm{pp}$.

Erdtman, G., 1952. Pollen Morphology and Plant Taxonomy, 1. Angiosperms. Almqvist and Wiksell, Stockholm, 539 pp.

ERDtman, G., 1960. The acetolysis method. A revised description. Svensk Botan. Tidskr., 54: $561-564$.

KöHLER, E., 1965. Die Pollenmorphologie der Biovulaten Euphorbiaceae und ihre Bedeutung für die Taxonomie. Grana Palynologica, 6: 26-120.

LÉANDR, J., 1958. In: H. HuMBerT, Flore de Madagascar, Euphorbiacées, 1. Firmin-Didot, Paris, 209 pp.

PuNT, W., 1962. Pollen morphology of the Euphorbiaceae with special reference to taxonomy. Wentia, $7: 1-116$.

WeBster, G. L., 1956-1958. A monographic study of the West Indian species of Phyllanthus.J. Arnold Arboretum (Harvard Univ.), 37 (1956): 91-122, 217-256, 340-357; 38 (1957): 51-79, 170-198, 295-372; 39 (1958): 49-100, 111-212.

Wrbster, G. L. and Ellis, J. R., 1962. Cytotaxonomic studies in the Euphorbiaceae, subtribe Phyllanthinae. Am. J. Botany, 49: 14-18. 